\title{
Ultrastructure and morphology of the elytrum of scale- worm Lepidonotus squamatus Linnaeus, 1767 (Polychaeta, Polynoidae)
}

\author{
N.B. Aneli', K.V. Shunkina ${ }^{2}$, V.B. Vays ${ }^{3}$, M.V. Plyuscheva ${ }^{4,5}$ \\ ${ }^{1}$ Experimental Factory for Scientific Engineering of the Russian Academy of Sciences. \\ ${ }^{2}$ Zoological Institute RAS, Laboratory of Evolutionary Biology, Saint-Petersburg, Russia. \\ ${ }^{3}$ A.N. Belozersky Institute of Physico-Chemical Biology, Moscow State University, Moscow, \\ Russia. \\ ${ }^{4}$ Centre for Genomic Regulation (CRG), The Barcelona Institute for Science and Technology, \\ Barcelona, Spain.E-mail: plyuscheva@gmail.com \\ ${ }^{5}$ Universitat Pompeu Fabra (UPF), Barcelona, Spain.
}

ABSTRACT: The prey defensive strategy of the scale-worms can be divided to 3 different strategies. First one is symbiosis, the second defense strategy is to autotomize scales, and the third defense strategy is to curl into the ring and to protect the body by thick scales with big and sharp tubercles. The aim of this paper is to present the morphological, ultrastructural, and immunohistochemical studies of the scale of Lepidonotus squamatus. Elytrum of L. squamatus is composed from a dorsal and ventral single-layered epithelium covered with cuticle. The middle compartment is crossed by the ramifications of a nervous plexus. Dorsal cuticle is thicker than ventral and bears numerical macrotubercles of irregular shape. Elytrum is innervated by a single ganglion, situated in the base of elytrophor. Both FMRFamide- and 5HT-positive elements are presented in the ganglion. Laterally thick nerve bundles emerge from the elytrum ganglion to the thickness of elytrum. In the proximal part some fine neural processes protrude between the lower lateral margins of the epithelial cells and go inside papillae. In the distal parts nerves are lying in the middle between dorsal and ventral epithelium. We suppose that nerve fibers of neuroglia form a "chanell" inside the tissue, which is filling elytrum.

How to cite this article: Aneli N.B., Shunkina K.V., Vays V.B., Plyuscheva M.V. 2017. Ultrastructure and morphology of the elytrum of scale-worm Lepidonotus squamatus Linnaeus, 1767 (Polychaeta, Polynoidae) // Invert. Zool. Vol.14. No.2. P.99-107. doi: 10.15298/invertzool.14.2.01

KEY WORDS: Scale-worms, elytrum, ultrastructure, epidermis, nerve system, defensive strategy.

\section{Ультраструктура и морфология элитр чешуйчатого червя Lepidonotus squamatus Linnaeus, 1767 (Polychaeta, Polynoidae)}

\author{
Н.Б. Анели ${ }^{1}$, К.В. Шунькина ${ }^{2}$, В.Б. Вайс ${ }^{3}$, М.В. Плющева ${ }^{4,5}$ \\ I Экспериментальный завод научного приборостроения РАН, Москва, Россия. \\ 2 Зоологический институт РАН, лаборатория эволючионной морфологии, Санкт-Петер- \\ бург, Россия. \\ ${ }^{3}$ НИИ физико-химической биологии им. А.Н. Белозерского, Московский государственный \\ университет им. М.В. Ломоносова, Москва, Россия.
}


${ }^{4}$ Центр Геномных Регуляиий (CRG), Институт Науки и Технологий Барселоны (BIST),
Барселона, Испания. Е-таil: plyuscheva@gmail.com
${ }^{5}$ Университет Помпеу Фабра (UPF), Барселона, Испания.

РЕЗЮМЕ: Можно выделить 3 варианта стратегии защиты от хищников у полиноид. Первая защитная стратегия — симбиоз, вторая — автотомирование элитр, третья способность скручиваться в колечко и защищать тело при помощи чешуек с большими и острыми туберкулами. Цель данного исследования описать строение элитры Lepidonotus squamatus с точки зрения морфологии, ультраструктуры и иммуногистохимии. Элитра L. squamatus состроит из двух однорядных эпителиев - дорсального и вентрального, покрытых кутикулой. В средней части элитры располагаются нервные волокна. Дорсальная кутикула толще вентральной и покрыта многочисленными крупными туберкулами неправильной формы. Элитру иннервирует непарный ганглий, расположенный в основании элитрофора. В ганглии обнаружены как серотонин- так и FMRFамид-положительные элементы. Латерально от ганглия в толщу элитры отходят крупные нервные стволы. В проксимальных частях элитры можно обнаружить тонкие нервные отростки, проходящие между нижними латеральными краями эпителиальных клеток и входящие в толщу папиллы. В дистальной части элитры нервы лежат посередине между дорсальным и вентральным эпителием. Мы предполагаем, что ткань, похожая на нейроглию формирует «каналы» в которых проходят нервы сквозь ткань, заполняющую толщу элитры.

Как цитировать эту статью: Aneli N.B., Shunkina K.V., Vays V.B., Plyuscheva M.V. 2017. Ultrastructure and morphology of the elytrum of scale-worm Lepidonotus squamatus Linnaeus, 1767 (Polychaeta, Polynoidae) // Invert. Zool. Vol.14. No.2. P.99-107. doi: 10.15298/invertzool.14.2.01

КЛЮЧЕВЫЕ СЛОВА: чешуйчатые черви, элитра, ультраструктура, эпидермис, нервная система, защитная стратегия.

\section{Introduction}

Among the segmented marine worms (Annelida, Polychaeta), the species of the order Polynoidae (together with some other like Pholoididae or Sigalionidae) are commonly known as scale-worms because their dorsal side is covered by ornamented scales (referred to as elytra). The series of paired elytrum are attached to dorsal prominences, called elytrophores, arising from the notopodia. The number of pairs of elytrum is constant within a genus, and varies from relatively few (7-21) to very numerous. Elytra can be minute or large and overlapping (covering the entire dorsum or leaving the mid-dorsum and posterior end uncovered), and can be smooth, covered with micro- or macrotubercles, or with fringed or smooth margins.

In the food chain polynoids are the source of food for bigger predators, like fishes. To protect themselves they have to evolve their own defen- sive strategies. Defensive strategy of the scaleworms can be divided to 3 different ways. First one is symbiosis, when worms just hide themselves or in the ambulacral groove of sea-stars, like Acholoe squamosa (Delle Chiaje, 1827), or in the mantle of sea slugs, like Arctonoe vittata (Grube, 1855). The second defense strategy is to autotomize scales, that after the detached process starting to glow that allows worm to escape from the predator like Harmothoe imbricata Linnaeus, 1767 and Malmgreniella lunulata (Delle Chiaje, 1830). In this case the elytra are moved by muscle and tendon cells and are provided with a rich variety of receptor cells (Anton-Erxleben, 1981) so that they just function as a neuro-ectodermic organ. The middle compartment is crossed by the ramifications of a nervous plexus ending in sencili, histochemically rich in cholinesterases (Bassot, Nicolas, 1995). The third defense strategy is to curl into a ring and to protect the body by thick scales 
armed with big and sharp tubercles, like Iphione muricata (Lamarck, 1818), Lepidonotus squamatus (Linnaeus, 1758) or L. clava (Montagu, 1808), in this case elytrum dehiscence occurs across a distinct line and only during strong mechanical stimuli (Storch, Alberti, 1995).

The morphology of symbiotic scale-worms and ultrastructure of photocites of bioluminescent ones, that autotomize scales are rather good studied (Bassot, Nicolas, 1995; Anctil et al., 1987; Miron, Anctil, 1988), but ultrastructural studies of elytrum have been held only for two species of scale-worms, Pholoe minuta (Fabricius, 1780) (Heffernan, 1990) and Iphione muricata (Storch, Alberti, 1995). The aim of this paper is to present the morphological, ultrastructural and immunohistochemical studies of the scale of Lepidonotus squamatus and to compare new data with the morphology of elytra of other scale-worms.

\section{Materials and methods}

\section{Electron microscopy}

The specimens of Lepidonotus squamatus were collected in Kandalaksha Bay (White Sea, $18-20 \mathrm{~m}$ depth) and kept alive in native marine water at $6-8{ }^{\circ} \mathrm{C}$. For transmission electron microscopy (TEM) elytra were fixed in 3\% glut- araldehyde solution in $0,1 \mathrm{M}$ phosphate buffer saline (PBS) $\left(\mathrm{pH} \mathrm{7.4)}\right.$ for $2 \mathrm{~h}$ at $4^{\circ} \mathrm{C}$, then overfixed in $1 \%$ osmium tetraoxide solution in buffer for $1.5 \mathrm{~h}$, and dehydrated in alcohol series with increasing alcohol concentrations (70\% alcohol was saturated with uranyl acetate). The material was embedded in an Epon-812 epoxy resin.

Serial ultrathin sections were made with a Leica UC6 microtome and stained by lead according to Reinolds (Reynolds, 1963). The resulting preparations were scanned and photographed using JEM-1400 electron microscope ("JEOL", Japan) and filmed using Olympus QUEMESA camera (Olympus Corporation, Japan).

\section{Immunohistochemistry}

For the visualization of FMRFamide- and 5HT-positive parts of the elytrum nervous system we used the standard method of immunohistochemical staining with antibodies against serotonin (Sigma, S5545) and FMRFamide (Immunostar, 20091) diluted 1:500 and the corresponding secondary antibodies Alexa Fluor ${ }^{\circledR}$ 488 (Invitrogen, A_11008) diluted 1:500. Staining was made by a standard protocol, widely used for different groups of invertebrates (Shunkina et al., 2015).

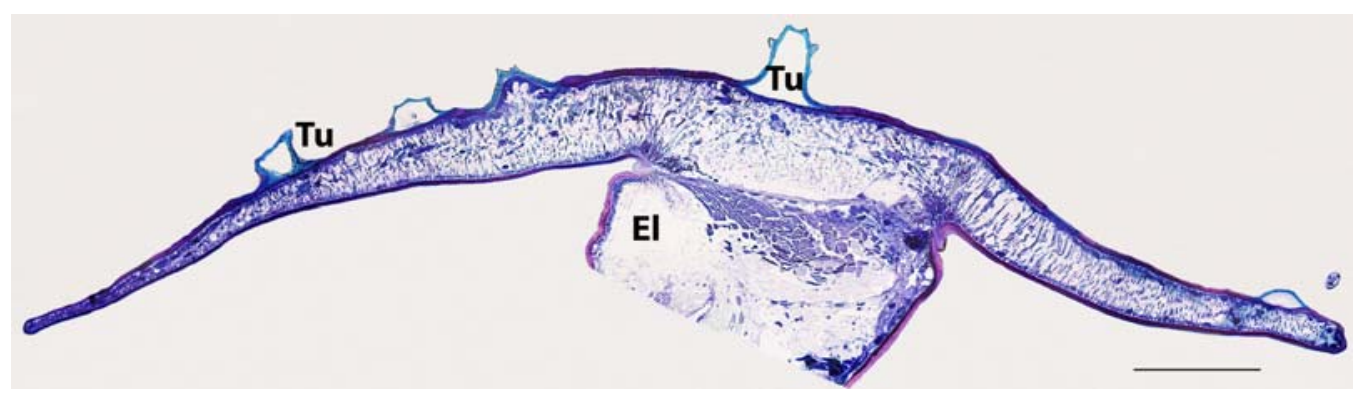

Fig. 1. Semi thin cross-section of Lepidonotus squamatus elytrum (methylene blue staining) showing macrotubercles on the dorsal side of the scale and middle compartment is crossed by the ramifications of a nervous plexus.

Abbreviations: El — elytrophore; Tu — tubercle. Scale bar - $400 \mu \mathrm{m}$.

Рис. 1. Полутонкий срез элитры Lepidonotus squamatus (окраска метиленовым синим). Хорошо заметны крупные туберкулы на дорсальной стороне элитры и внутреннее пространство, в котором располагаются нервы.

Обозначения: $\mathrm{El}$ — элитрофор; Тu — туберкула. Масштаб $400 \mu \mathrm{m}$. 


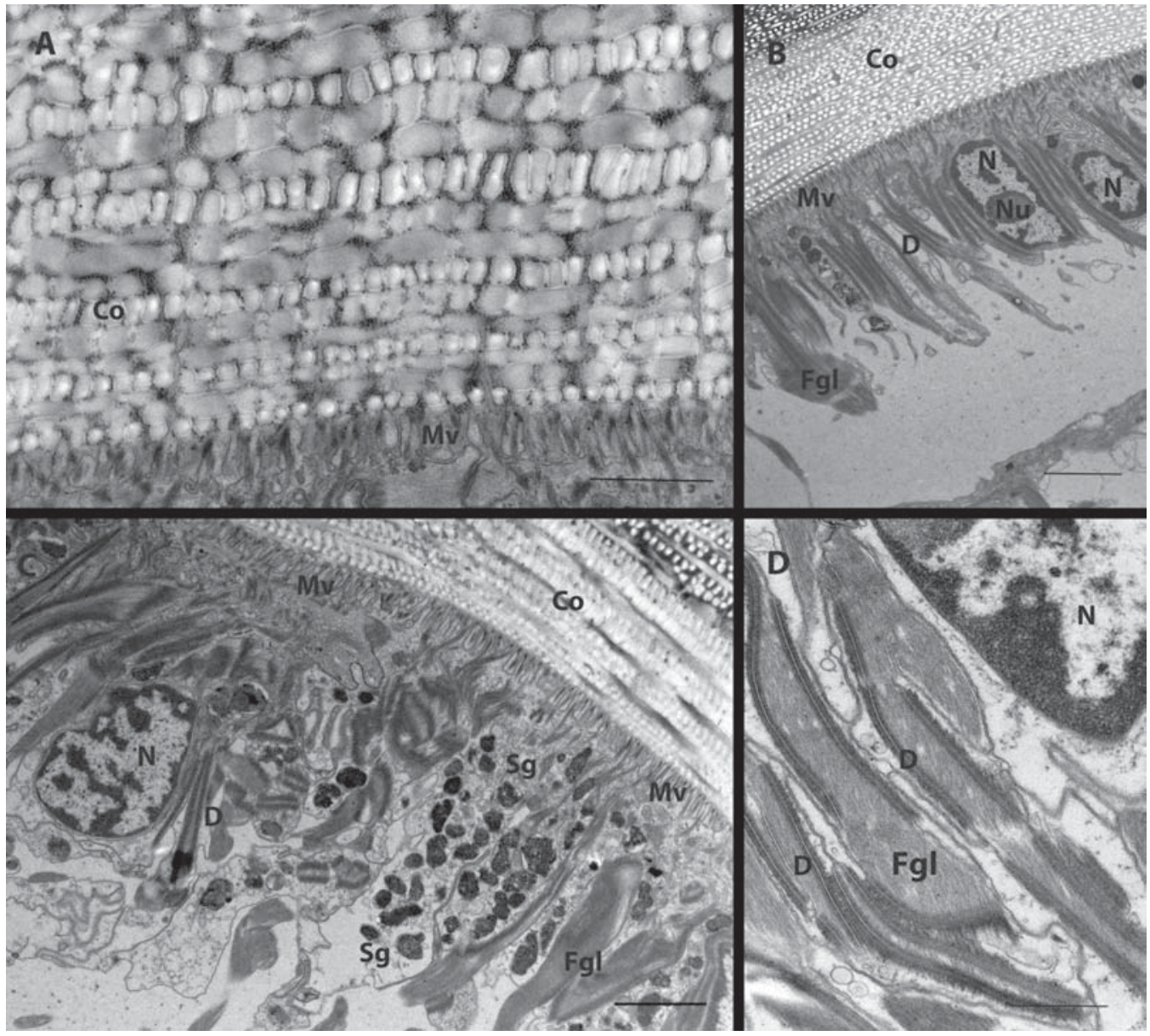

Fig. 2. Different areas of elytrum cuticle and epithelium in Lepidonotus squamatus (TEM). A - collagen organization of dorsal cuticle; B - supportive cells of dorsal epithelium; C - secretory cells of dorsal epithelium; D - desmosomes.

Abbreviations: Co - collagen fibers; D - desmosomes; $\mathrm{Fgl}$ - fibers of neuroglia; $\mathrm{Mv}$ - microvilli; $\mathrm{N}$ - nucleus; $\mathrm{Nu}$ - nucleoli; $\mathrm{Sg}$ - secretory granules. Scale bar: A, D $-1 \mu \mathrm{m} ; \mathrm{B}, \mathrm{C}-2 \mu \mathrm{m}$.

Рис. 2. Разные участки кутикулы и эпителия элитры Lepidonotus squamatus (TEM). А — строение коллагена дорсальной кутикулы; В - поддерживающие клетки дорсального эпителия; C - секреторные клетки дорсального эпителия; D - десмосомы.

Обозначения: Сo - коллагеновые волокна; D - десмосомы; $\mathrm{Fgl}$ - волокна нейроглии; $\mathrm{Mv}$ - микровилли; $\mathrm{N}$ - ядро; $\mathrm{Nu}$ - ядрышко; $\mathrm{Sg}$ - секреторные гранулы. Масштаб: A, D $-1 \mu \mathrm{m} ; \mathrm{B}, \mathrm{C}-2 \mu \mathrm{m}$.

\section{Results and discussion}

Lepidonotus squamatus carries 12 pairs of elytra with almost roundish anterior pair and more oval at the posterior end. Dorsal side of scales is covered by macrotubercles (Plyuscheva et al., 2017; Plyuscheva, Martin, 2009) and papillae (Fig. 1). Elytrum of L. squamatus is composed of a dorsal and ventral single-layered epithelium covered by a cuticle. The middle compartment is crossed by the ramifications of a nervous plexus, like in autotomizing scaleworm Harmothoe imbricata (Miron et al., 1987) (Fig. 2). 


\section{Dorsal cuticle}

Dorsal cuticle is formed by thin layer of epicuticle $0.536 \mu \mathrm{m}$ and parallel layers of collagen fibrils arranged in orthogonal order of $0.177 \mu$ m medial thickness. The thickness of the dorsal cuticle varies from 11.85 to $18.5 \mu \mathrm{m}$, that's several times thicker than in H. imbricata (Miron et. al., 1987). Small electron dense granules could be observed in-between the fibers (Fig. 2A).

The dorsal side of scale covered with numerical macrotubercles of irregular shape. In cuticle organisation of tubercle 3 layers can be distinguished: electron-dense external without collagen fibrils, less dense middle layer with chaotically organized collagen fibrils and electron-dense internal one with rare inclusions of collagen fibrils, internal cavity is empty (Figs 1, $3 \mathrm{~A})$. These data confirm the description of Iphione muricata (Storch, Alberti, 1995), but in that case authors do mistake and call macrotubercles, that are one of the specie-specific characters, as "polygonal areas".

\section{Dorsal epithelium}

A single layer of epithelial cells is located under the dorsal cuticle. A simple, cuboidal epithelium consists of cells combining features of both supportive and secretory cells. The apical surface of epithelial cells bears microvilli, which penetrate into the cuticle and extend through all the layers of collagen fibrils till the epicuticle. The main part of epithelial cell is occupied by nucleus of irregular shape (Fig. 2B, C, D).

\section{Nervous system}

Elytrum is innervated by a single ganglion, situated in the base of elytrophor. Both FMRFamide- and 5HT-positive elements are presented in the ganglion (Fig. 3B, C). Laterally thick nerve bundles emerge from the elytrum ganglion to the thickness of elytrum. In the proximal part some fine neural processes protrude between the lower lateral margins of the epithelial cells and go inside papillae. In the distal parts nerves are lying in the middle between dorsal and ventral epithelium. Nerve processes, pass- ing to the most distal edge of elytrum are surrounded by a lot of cells (which nuclei could be clearly seen on immunohistochemical images). We suppose that nerve fibers of neuroglia form a "channel" inside the tissue, which is filling elytrum (Anctil et al., 1987; Miron, Anctil, 1988; Heffernan, 1990). Possibly, these cells form some kind of neuroglial channel around nerves. Earlier neuroglia was found in the ventral nerve cord of different polychaetes of family Nereidae (Baskin, 1971) and that is supposed to be the main component of the peripheral nerve system. Glia binds single elements of neuropile, forming a structure like a wrapped cable (Fig. 4). Probably, this neuroglial "channel" secures nerve fibers, innervating the most distal part of elytrum and also forms a support structure - some kind of internal compartmentalization - for the nerve processes.

\section{Ventral epithelium}

Ventral epithelium is composed of supportive cells of squamous shape and equipped with standard organelles (Hausen, 2005) (Fig. 5A, C).

\section{Ventral cuticle}

Ventral cuticle organized by thin layer of epicuticle $0,536 \mu \mathrm{m}$ and parallel layers of collagen fibrils arranged in orthogonal order of 0.125 to $0.250 \mu \mathrm{m}$ thickness (Fig. 5B). The thickness of the ventral cuticle varies from 11.85 to $18.5 \mu \mathrm{m}$, that almost 2 times less, that the dorsal cuticle. In-between the fibers could be observed small electron dense granules with the size of $0.125 \mathrm{~nm}$.

Within the differences that we can observe between the structure of dorsal and ventral cuticle we can support the theory of Storch and Alberti (1995) that in case of non-autotomizing scale-worms elytra serve the purposes of protection against predators.

\section{Acknowledgements}

The authors are very grateful to the staff of White Sea Biological Station of Moscow State University for the help in worm collection with special thanks to Alexander Semenov, the chief of diving facility for diving assistance. We would 

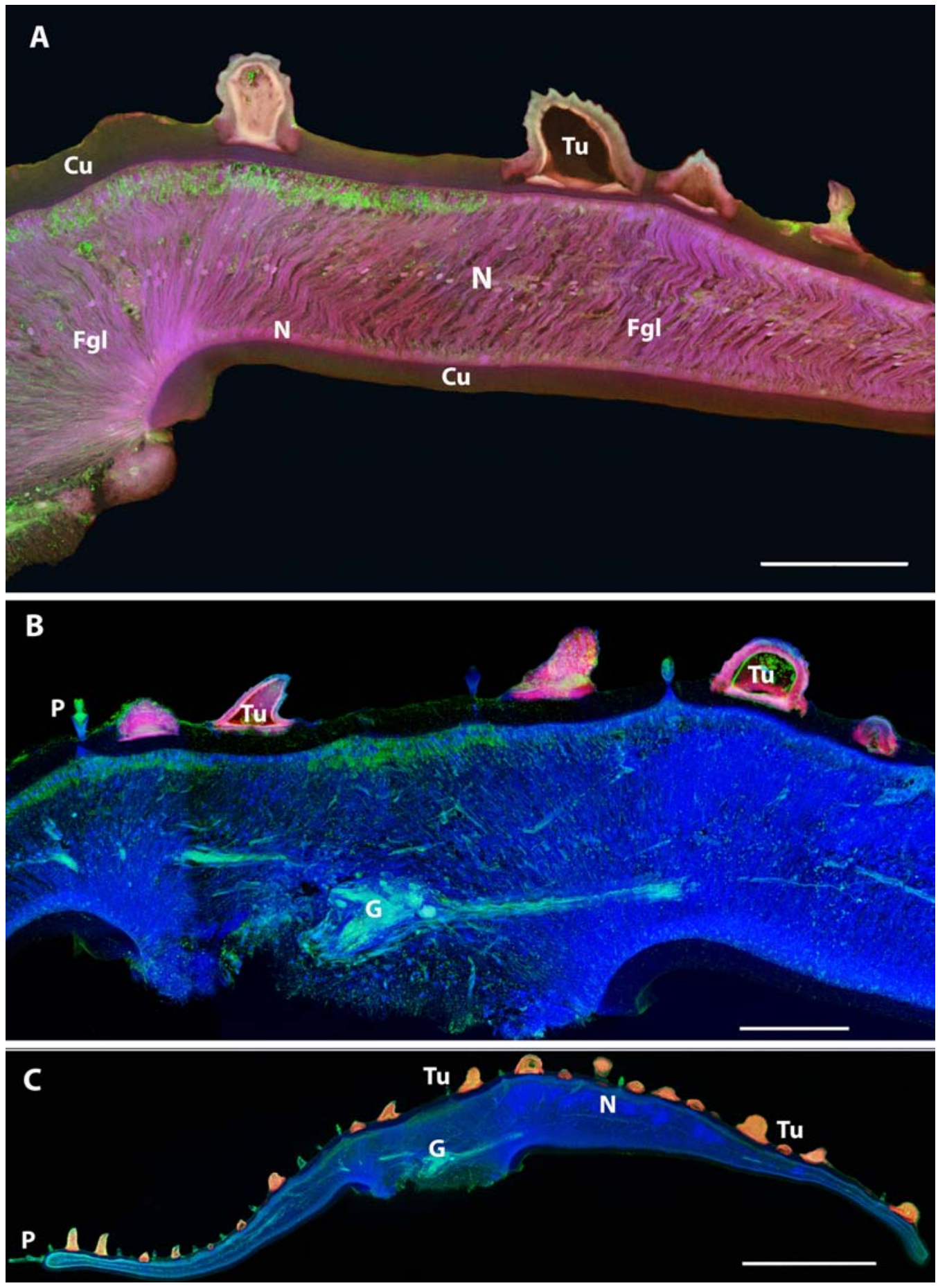

Fig. 3. Nervous system of Lepidonotus squamatus elytra (immunocytochemistry and laser confocal scanning microscopy); Z-projections. A - cross-section of elytrum, stained with anti-FRMF-amide antibodies and Bodipy stain for cell membranes, showing fibres of neuroglia, crossing all the internal compartment of the 


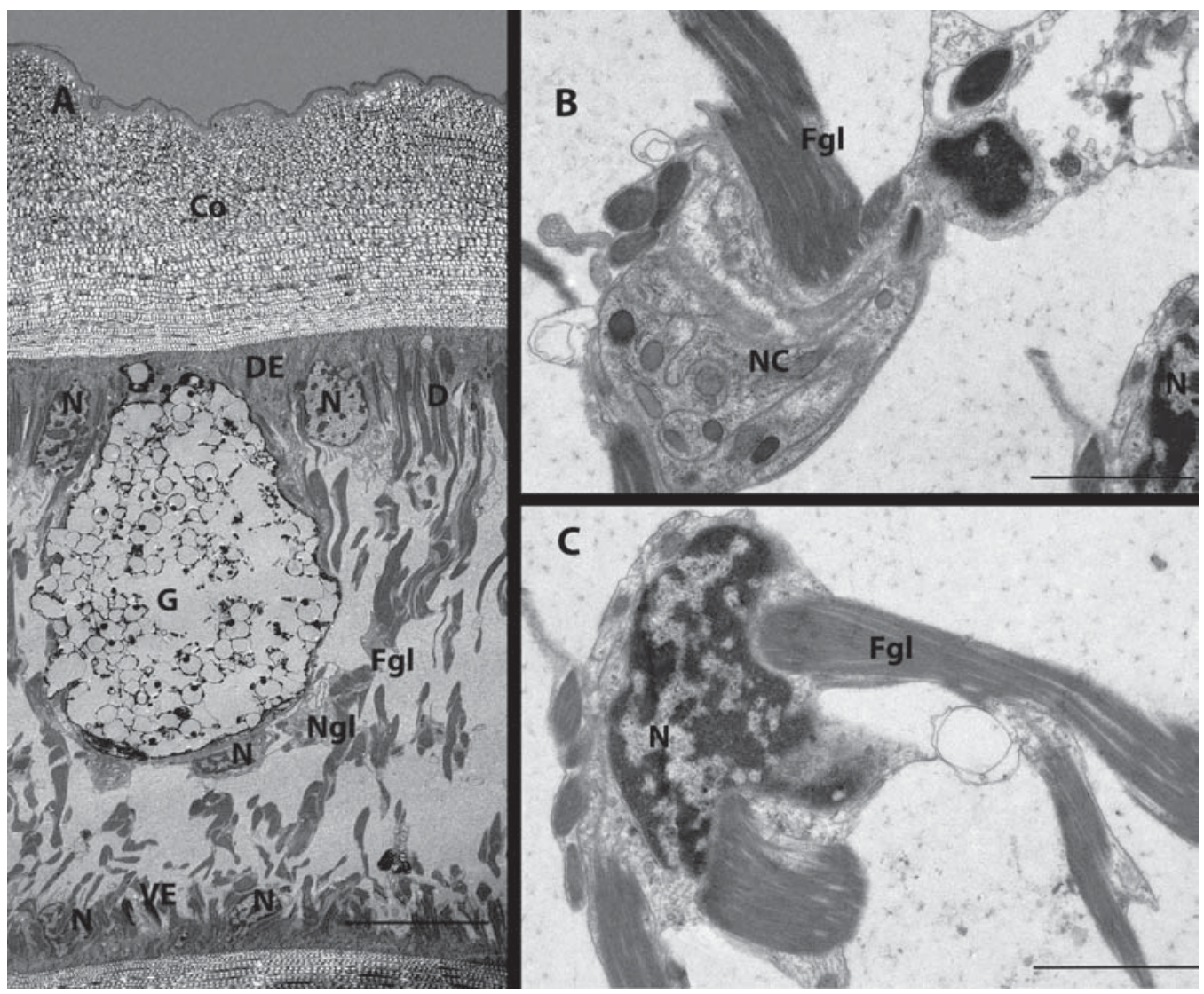

Fig. 4. Ganglion and neuronal supportive cells of Lepidonotus squamatus elytra (TEM). A — ganglion, surrounded by supportive glial cells and connected via desmosomes to dorsal epithelial cells; B, C neuronal supportive cell.

Abbreviations: D - desmosomes; DE - dorsal epithelium; Fgl - fibers of neuroglia; $\mathrm{G}$ - ganglion; $\mathrm{N}$ - nucleus; $\mathrm{Ngl}$ - neuroglia; NS - nerve cell. Scale bar: A - $10 \mu \mathrm{m} ; \mathrm{B}, \mathrm{C}-2 \mu \mathrm{m}$.

Рис. 4. Ганглий и вспомогательные клетки нервов элитры Lepidonotus squamatus (TEM). А ганглий, окруженный вспомогательными клетками; В,C - вспомогательная клетка нерва.

Обозначения: D — десмосомы; DE — дорсальный эпителий; $\mathrm{Fgl}$ — волокна нейроглии; $\mathrm{G}$ — ганглий; $\mathrm{N}$ — ядро; $\mathrm{Ngl}$ - ядрышко; NS - нервная клетка. Масштаб: A - $10 \mu \mathrm{m}$; B, C $-2 \mu \mathrm{m}$.

elytrum; B - anti-FRMF visualization of nervous system; C - anti-5HT visualization of nervous system. Specific antibody signal is green, nuclei are blue, autofluorescence of macrotubercles is orange. Abbreviations: $\mathrm{Cu}-$ cuticle; Fgl - fibers of neuroglia; $\mathrm{G}$ - ganglion; $\mathrm{N}$ - nerve; $\mathrm{P}$ - papilla; $\mathrm{Tu}$ - tubercle. Scale bar: $\mathrm{A}, \mathrm{C}-100 \mu \mathrm{m}$; B $-500 \mu \mathrm{m}$.

Рис. 3. Нервная система элитры Lepidonotus squamatus (по данным иммуноцитохимического окрашивания и лазерной конфокальной микроскопии); Z-проекции. A - поперечный срез элитры, окрашенный антителами к FMRFамиду и Bodipy (окраска клеточных мембран). Показаны волокна нейроглии, проходящие в толще элитры; В - визуализация FMRFамидергической части нервной системы; C - нервные элементы, окрашенные антителами против серотонина.

Оранжевый - автофлуоресценция макротуберкул; C - визуализация серотонинергической части нервной системы, ядер. Оранжевый - автофлуоресценция макротуберкул. Обозначения: $\mathrm{Cu}$ - кутикула; $\mathrm{Fgl}$ - волокна нейроглии; G — ганглий; N — нерв; P — папилла; Тu — туберкула. Масштаб: А, C - $100 \mu \mathrm{m} ; \mathrm{B}-500 \mu \mathrm{m}$. 


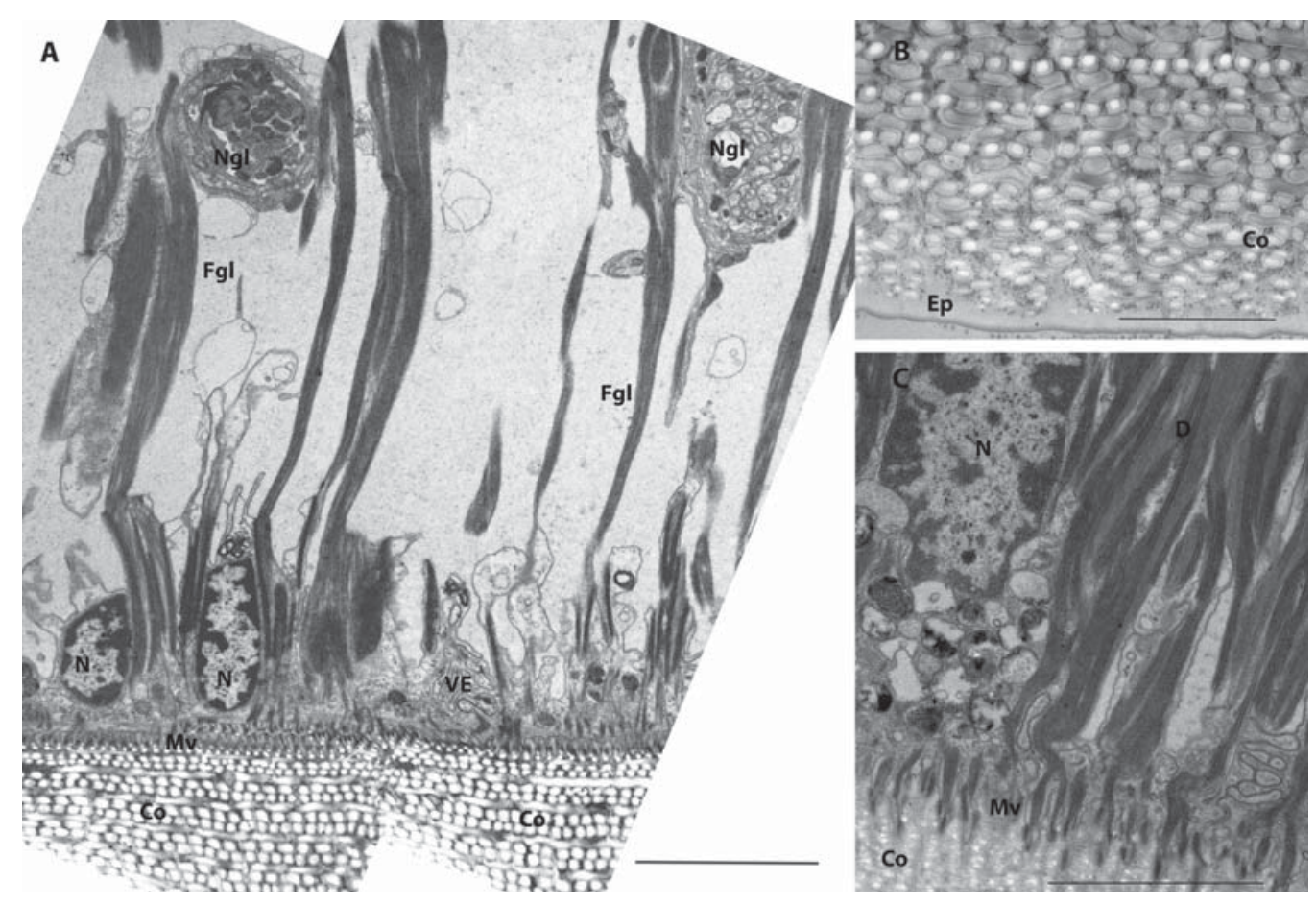

Fig. 5. Ventral epithelium and cuticle of Lepidonotus squamatus elytra (TEM). A — ventral epithelial cells, connected by desmosomes to supportive cells of neuroglia; $\mathrm{B}$ - cuticle; $\mathrm{C}$ - desmosomes.

Abbreviations: $\mathrm{Co}$ - collagen fibers; Ep - epicuticle; Fgl — fibers of neuroglia; $\mathrm{N}$ - nucleus; $\mathrm{Ngl}$ - neuroglia; $\mathrm{Mv}-$ microvilli; VE - ventral epithelium. Scale bar: A $-4 \mu \mathrm{m}$; B $-1 \mu \mathrm{m} ; \mathrm{C}-2 \mu \mathrm{m}$.

Рис. 5. Вентральный эпителий и кутикула элитры Lepidonotus squamatus (TEM). А — вентральные эпителиальные клетки, связанные десмосомами с вспомогательными клетками нейроглии; В кутикула; $\mathrm{C}$ - десмосомы.

Обозначения: Сo - коллагеновые волокна; D - десмосомы; $\mathrm{Ep}$ - эпикутикула; $\mathrm{Fgl}$ - волокна нейроглии; $\mathrm{N}$ - ядро; $\mathrm{Ngl}$ - нейроглия; $\mathrm{Mv}$ - микровилли; $\mathrm{VE}$ — вентральный эпителий. Масштаб: $\mathrm{A}-4 \mu \mathrm{m} ; \mathrm{B}-1 \mu \mathrm{m}$; $\mathrm{C}-2 \mu \mathrm{m}$.

like to thank Elena Temereva for her supervision and help to the first author during TEM sample preparation and for wise advices during manuscript application.

The work was supported by HHMI International Early Career Scientist Program (55007424), the MINECO (BFU2012-31329 and BFU2015-68723-P), Spanish Ministry of Economy and Competitiveness Centro de Excelencia Severo Ochoa 2013-2017 grant (SEV2012-0208), Secretaria d'Universitats i Recerca del Departament d'Economia i Coneixement de la Generalitat's AGAUR program (2014 SGR 0974), and the European Research Council under the European Union's Seventh Framework Programme (FP7/2007-2013, ERC grant agreement (335980_EinME). We acknowledge the support of the CERCA Programme / Generalitat de Catalunya. The study was supported by a grant of Russian Science Foundation (project No. 14-50-00029) and by a budget project ${ }^{1}$ AAAA-A17-117030110029-3 (ZIN RAS).

\section{References}

Anctil M., Bassot J.-M., Nicolas M.-T. 1989. Effects of monoamines and related drugs on the bioluminescence of scale-worm elytrum (Polychaeta, Polynoidae) // Comp. Biochem. Physiol. Vol.93C. P.127-135.

Anton-Erxleben F. 1981. Investigations of the cuticle of Polychaete elytrume using energy dispersive x-ray analysis // Helgoländer Meeresuntersuchungen. Vol.34. P.439-450. 
Baskin D. 1971. Fine structure functional organization and supportive role of neuroglia in Nereis // Tissue and Cell. Vol.3. P.579-588.

Bassot J-M., Nicolas G. 1995. Bioluminescence in scaleworm photosomes: the photoprotein polynoidin is specific for the detection of superoxide radicals // Histochemistry and Cell Biology. Vol.104. P.199210.

Hausen H. 2005. Comparative structure of the epidermis in polychaetes (Annelida) // Hydrobiologia. Vol.535/ 536. P.25-35.

Heffernan P. 1990. Ultrastructural studies of the elytrum of Pholoe minuta (Annelida: Polychaeta) with special reference to functional morphology // Journal of the Marine Biological Association of the United Kingdom. Vol.70. No.3. P.545-556. doi:10.1017/ S0025315400036572

Miron M-J., LaRivière L., Bassot J-M., Anctil M. 1987. Immunohistochemical and radioautographic evidence of monoamine-containing cells in bioluminescent elytra of the scale-worm Harmothoe imbricata (Polychaeta) // Cell Tissue Res. Vol.249. P.547-556. doi: $10.1007 / \mathrm{BF} 00217326$

Miron M-J., Anctil M. 1988. Serotonin-like immunoreactivity in the central and peripheral nervous system of the scale worm Harmothoe imbricata (Polychaeta) // J. Comp. Neurol. Vol.275. P.429-440.
Plyuscheva M., Pereira da Silva K., Aneli N., Vays V., Kondrashov F., Goñi A. 2017. Two-color fluorescence in elytra of the scale-worm Lepidonotus squamatus (Polychaeta, Polynoidae): in vivo spectral characteristic // Materials Today: Proceedings. In press.

Plyuscheva M., Martin D. 2009. Morphology of elytra as luminescent organs in scale-worms (Polychaeta, Polynoidae) // Proceedings of the Ninth International Polychaete Conference, Zoosymposia. Vol.2. P.379389.

Reynolds E.S. 1963. The use of lead citrate at high $\mathrm{pH}$ as an electron-opaque stain in electronmicroscop // J.Cell.Biol. Vol.17(208). P.212.

Shunkina K.V., Zaytseva O.V., Starunov V.V., Ostrovsky A.N. 2015. Comparative morphology of the nervous system in three phylactolaemate bryozoans // Frontiers in Zoology. Vol.12: 28. DOI 10.1186/s12983015-0112-2

Storch V., Alberti G. 1995. Elytrum of Iphione muricata (Lamarck, 1818): a reinterpretation of its architecture based on TEM // Mitteilungen aus dem Hamburgischen Zoologischen Museum und Institut. Bd.92. P.103-124.

Responsible editor E.N. Temereva 